\title{
WHEN DID BRITAIN INDUSTRIALISE? THE SECTORAL DISTRIBUTION OF THE LABOUR FORCE AND LABOUR PRODUCTIVITY IN BRITAIN, 1381-1851
}

\author{
Stephen Broadberry, London School of Economics, S.N.Broadberry@1se.ac.uk \\ Bruce M. S. Campbell, The Queen's University of Belfast, b.m.campbell@ qub.ac.uk \\ Bas van Leeuwen, University of Warwick, bas.vanleeuwen1@googlemail.com
}

18 December 2011

File: SectoralSharesGB13c

\begin{abstract}
Britain's labour force industrialised early. The industrial and service sectors already accounted for 40 per cent of the labour force in 1381, and a substantial further shift of labour out of agriculture occurred between 1522 and 1700. From the early seventeenth century rising agricultural labour productivity underpinned steadily increasing employment in industry and services, so that by 1759 agriculture's share of the labour force had shrunk to 37 per cent and industry's grown to 34 per cent. Thereafter, industry's output acceleration during the Industrial Revolution owed more to gains in labour productivity consequent upon mechanisation than the expansion of employment.
\end{abstract}

JEL classification: $\mathrm{J} 21, \mathrm{~N} 13, \mathrm{~N} 33, \mathrm{O} 14, \mathrm{O} 52$

Key words: Labour force, sectoral distribution, labour productivity, Britain

Acknowledgements: This paper forms part of the project "Reconstructing the National Income of Britain and Holland, c.1270/1500 to 1850", funded by the Leverhulme Trust, Reference Number F/00215AR. It is also part of the Collaborative Project HI-POD supported by the European Commission's 7th Framework Programme for Research, Contract Number SSH7-CT-2008-225342. We are grateful to Leigh Shaw-Taylor for making available unpublished data on sectoral labour-force shares and for helpful discussions. We have also benefited from the comments of participants in workshop presentations at Cambridge, Durham and Venice. The editors and anonymous referees made a number of particularly useful suggestions which helped to improve the exposition of the argument. Data digitisation was undertaken at the Centre for Data Digitisation and Analysis, The Queen's University of Belfast. 


\section{INTRODUCTION}

Modern revisions to the story of Britain's industrialisation raise awkward questions about comparative advantage prior to and during the initial phase of the Industrial Revolution. Deane and Cole's (1967) once influential account of British economic development since 1688 was premised on an eighteenth-century agricultural revolution which released labour to industry at the very time that mechanisation and the division of labour were raising the productivity of labour in manufacturing. British-made goods thereby became unbeatable in World markets so that industry became the most dynamic employment sector within a fastgrowing economy. Agricultural historians, however, in an important revision to this narrative, now see the agricultural revolution as having begun much sooner, in the early seventeenth century, so that agriculture's labour-force share was already much reduced before the industrial revolution got under way. The output estimates of Crafts (1985) and Crafts and Harley (1992) endorse this revision and, in turn, propose that industrial growth was slower during the eighteenth century than estimated by Deane and Cole, notwithstanding the continued transfer of labour out of agriculture and into industry. On this revised scenario eighteenth-century agriculture was more successful at shedding labour than industry was at expanding output. Hence the paradox that, at the very time that Britain was becoming the workshop rather than the granary of the world (Crafts, 1989), productivity growth in agriculture apparently exceeded that in industry.

To resolve this paradox this paper reconstructs the labour-force and output shares of the three principal sectors of agriculture, industry and services between 1381 and 1851 . The labour-force estimates are reconstructed for benchmark years using the Poll Tax Returns of 1381, the Muster Rolls of 1522, and re-worked social tables for 1700, 1759, 1801 and 1851, paying particular attention to the differing sectoral participation rates of male and female 
workers. These estimates are then combined with reconstructions of sectoral output from Broadberry et al. (2011) to chart the growth of labour productivity by sector. Commencing from a firmly established late-medieval base, the critical structural shift of labour away from agriculture to industry occurred during the early modern period of vigorous proto-industrial growth. So much progress had been made by 1700 that the shift of labour from agriculture to industry during the eighteenth century was smaller than that proposed by Crafts and Harley, thereby reinstating industry as the sector with the fastest labour productivity growth during the classic Industrial Revolution period. Although there was also substantial agricultural labour productivity growth between 1700 and 1851, it was at a slower pace than in industry, thus reversing the most paradoxical finding of Crafts and Harley (1992). Yet while these findings reconcile the output estimates of Clark and Harley with traditional views of an industrially dynamic Industrial Revolution they challenge those of Clark (2011), who argues for little or no trend growth in per capita incomes before 1800 and a relatively late final shift of labour out of agriculture. A critical evaluation of Clark's estimates thus comprises the final section of the paper.

\section{THE SHIFT OF LABOUR OUT OF AGRICULTURE}

One way to answer the question "when did Britain industrialise?" is to reconstruct the shares of the labour force engaged in the three main sectors of agriculture, industry and services for a number of benchmark years. Relevant data are available for the territories of England between 1381 and 1700 and Great Britain between 1700 and 1851.

\section{Labour force shares from the $\mathbf{1 3 8 1}$ Poll Tax Returns}

The Poll Tax Returns of 1381, made accessible recently in Fenwick (1998; 2001; 2005), provide the earliest securely documented basis for estimating the occupational structure of 
England. Information is available for 30,292 individuals (approximately 2 per cent of total adults), resident in 892 villages, covering 95 hundreds in 22 counties stretching across England from Kent in the southeast to Lancashire in the northwest and Dorset in the southwest to Yorkshire in the northeast.

A particular strength of the Poll Tax returns is that information is given on female as well as male occupations, which are treated separately in Parts A and B of Table 1. The first step in derivation of the results summarised in this table involved allocating male and female workers with known occupations across agriculture, industry and services using Wrigley's (2006) Primary-Secondary-Tertiary (PST) scheme, but with mining included in the industrial sector, as in Shaw-Taylor (2009a). The 15.0 per cent of male workers and 16.4 per cent of female workers with the non-sector specific designation 'labourer' present a particular problem, common to all the pre-census benchmark data. They have been assigned to agriculture and non-agriculture in proportion to the identified workers in these sectors, but with all non-agricultural labourers allocated to industry (the results are not particularly sensitive to this procedure, since for example, if labourers were allocated in proportion to the shares of identified workers in all sectors, there would be no change to the share of agriculture but an improbable 4.4 per cent of the labour force would be redistributed from industry to services). Finally, because the sample is biased towards urban and semi-rural areas, it has been re-weighted using data from the Cambridge Urban History of Britain to accord with national rural, urban and semi-rural proportions of 80 per cent, 10 per cent and 10 per cent. Thus, vills with more than 70 per cent of occupations in agriculture are treated as rural, towns with more than 2,000 inhabitants identified by Dyer (2000) are classified as urban, and the remainder are deemed to be semi-rural. 
The sectoral distribution of the total labour force in 1381 (Table 1B) is obtained by combining the separate occupational breakdowns for males and females. Females are assumed to have worked 30 per cent of the total number of days worked in the economy. This ratio is derived from the mid-nineteenth century data, where Shaw-Taylor (2009a) found a male participation rate of 97.1 per cent and a female participation rate of 43.0 per cent (i.e. equivalent to 70 per cent male and 30 female labour-force shares). Although Field and Erickson (2009) appear to suggest higher rates of female participation during the pre-modern period, it should be noted that they are referring to women active in the labour market, irrespective of how many days they actually worked. From the perspective of labour productivity, it is also more helpful to think in terms of the proportion of days worked by women. On a full-time equivalent basis, it seems highly unlikely that women could have worked much more than 30 per cent of total days worked, given the unequal distribution of child-rearing and household duties in pre-modern times. At the other end of the chronological spectrum, the Poll Tax returns suggest females accounted for just 16.8 per cent of the labour force, which seems far too low. Fortunately, the results are not particularly sensitive to this range of female proportions. On the assumption that females accounted for 30 per cent of employment, around 60 per cent of the labour force in 1381 were engaged in agriculture, while, of the remainder, slightly more were engaged in services than in industry. ${ }^{1}$ This places a considerably lower share of the labour force in agriculture during the late-medieval period than has hitherto been assumed, with Overton and Campbell (1996) and Allen (2000), for example, assuming shares in the range $75-80$ per cent. It is, however, broadly consistent with the results of Clark (2011), derived by a different method from the 1381 Poll Tax Returns.

\footnotetext{
${ }^{1}$ Note that even if females did account for 16.8 per cent of employment, the total labour-force shares would change relatively little to 64.1 per cent in agriculture, 14.8 per cent in industry and 21.1 per cent in services.
} 


\section{Labour force shares from the 1522 Muster Rolls}

The Muster Rolls or military surveys of 1522 are the next set of records with usable occupational information. Although these were carried out across the whole country, disappointingly, only three of the surviving surveys record occupations systematically: Coventry (Hulton, 1999), representative of an urban environment; Babergh Hundred in Suffolk (Pound, 1981), diagnostic of a semi-rural environment; and Rutland (Cornwall, 1980), an example of a rural environment. Self-evidently, this is a smaller and geographically less comprehensive sample than the 1381 Poll Tax Returns and is further handicapped by relating almost exclusively to males.

Table 2A shows the distribution of the labour force in the three districts and in the sample as a whole. The weightings are taken from the Cambridge Urban History of Britain and again assume rural, urban and semi-urban proportions respectively of 80 per cent, 10 per cent and 10 per cent (Barron, 2000; A. Dyer, 2000; C. Dyer, 2000; Kermode, 2000). As in the Poll Tax Returns, the Muster Rolls contain a category of workers designated simply as "labourers". These comprise 25.9 per cent of those listed and in Table 2B are similarly assigned to agriculture and non-agriculture in proportion to the identified workers in these sectors, but with all non-agricultural labourers allocated to industry (allocating the nonagricultural labourers in proportion to the shares of identified workers in industry and services would redistribute 2.8 per cent of the labour force to services). The occupational estimates for females given in Table 2B depend upon two basic assumptions: first, that women worked 30 per cent of the total number of days worked in the economy and, second, that sectoral participation by female workers proportionately the same as in 1381 . 
The final column of Table $2 \mathrm{~B}$ combines the male and female data to provide an estimate of the total sectoral distribution of the labour force. Around 60 per cent were still employed in agriculture, a proportion broadly in line with the findings of Clark et al. (2010) based upon testamentary information for the mid-sixteenth century (Table 9C). Of the remaining workers, slightly more were now engaged in industry than in services.

\section{Labour-force shares from social tables circa 1700,1759 and 1801}

Recent work by Shaw-Taylor (2009a) and Shaw-Taylor et al. (2010) has provided estimates of the male labour force during the eighteenth century, which suggests that much of the shift of labour from agriculture to industry that earlier writers attributed to the period after 1750 had already occurred by 1710 . This important pioneering work on a large sample of baptism registers puts the share of the male labour force in agriculture in c.1710 at 43.0 per cent, which is a dramatic decline from our estimate of 68.3 per cent in 1522 . The share of the male labour force in agriculture in 1755 , at 44.0 per cent, was roughly the same as in 1710 , and by 1813-20 the share had fallen only to 35.4 per cent.

Given the provisional nature of the Shaw-Taylor et al. (2010) results plus the need for data on females as well as males, in this paper the occupational structures for circa 1700, 1759 and 1801 have been derived from social tables produced by political arithmeticians and historical demographers at the time (King, 1696, Massie, 1760; Colquhoun, 1806). As Maddison (2007: 252-84) notes, these writers had access to a rich array of data sources, including parish registers containing valuable information on occupations in association with demographic details of the life-cycle events of birth, marriage and death. They also had access to genealogical and heraldic information on high-status families, as well as detailed information on specific tax revenues. Colquhoun [1806] even had access to the first 
population census as well as parliamentary surveys of paupers and taxation data on the richest families. Furthermore, King [1696] organised his own mini-censuses for Lichfield, Harfield and Buckfastleigh, as a cross-check. The social tables produced by these pioneers of national income accounting have been reworked on a consistent basis by Lindert and Williamson (1982) and Crafts (1985), but without making any explicit allowance for the different occupational structures of males and females. The latter omission is significant, since it is clear from the recent work of Shaw-Taylor (2009a) and Shaw-Taylor et al. (2010) that the occupational distributions of 'families' in Colquhoun's, Massie's and King's social tables de facto correspond to those of males, and take little or no account of the contrasting occupational distributions of females. Allowance for this gender difference in occupations naturally needs to be made when assessing trends in total employment by sector.

Table 3 sets out King's social table for circa 1700. Part A presents the basic data on the number of families in each occupational grouping, as reworked by Lindert and Williamson (1982). To King's total of 1,390,586 families, Crafts (1985: 14) recommends adding 10 per cent for domestic service. Since King's occupational distribution applies primarily to males, and around three-quarters of domestic servants were females, a more modest allowance of just 2.5 per cent has been made for domestic service. Following Crafts (1985: 14), the titled aristocracy, gentlemen and vagrants are all classified as unoccupied, and, notwithstanding an amount of by-employment (see Section II.5 below), the occupied labour force allocated unambiguously between agriculture, industry and services, as indicated in Table 3. Rather than allocate all un-specified labourers, cottagers and paupers to agriculture, as did Crafts (1985), 31.8 per cent have been apportioned to industry and the remaining 68.2 per cent to agriculture (in line with the corresponding ratio for 1522). 
In Part B of Table 3, female employment is distributed across sectors in line with the estimates for 1813-20 given by Shaw-Taylor (2009a). Again, in accordance with the situation at the beginning of the nineteenth century (Shaw-Taylor, 2009a), females are assumed to have accounted for 30 per cent of the total number of days worked in the economy. By 1851 Shaw-Taylor (2009a) finds that female labour-force participation had risen to 43.0 per cent but it then fell back to 35.1 per cent in 1911, at a time when the male participation rate was close to 100 per cent (equivalent to a decline in the female share of the labour force from approximately 30 per cent to 25 per cent). Further research may uncover earlier fluctuations in female labour-force participation, but until such evidence is forthcoming the female share of the labour force is assumed to have been a constant 30 per cent before the mid-nineteenth century. This is consistent with the work of Humphries (2010: 107), who finds no evidence from a sample of autobiographies to support the idea of a change in women's aggregate participation rates during the eighteenth century, despite the large literature on the supposed effects of industrialisation on women's employment. Probably, too, any influence of temporal variations in the female participation rate upon sectoral labour productivity trends was dwarfed by the far greater gender differences in the sectoral distribution of employment, for which full allowance has been made.

For 1759, the basic 'family' (i.e. male) data for Joseph Massie's social table are set out in Table 4A. For consistency, an allowance of 2.5 per cent is made for omitted male domestic servants, male labourers are divided between agriculture and industry in the ratio 31.8 to 68.2 and, in Table 4B, the $1813-20$ sectoral employment distribution is used to allocate females to occupations, who are assumed to have accounted for 30 per cent of the labour force. Similar procedures are followed for circa 1801 using Colquhoun's [1806] social table. The basic data on the number of 'families' (de facto males) in each occupational 
grouping are set out in Table 5A and Table 5B allocates occupations across sectors following the same assumptions as for 1700 and 1759.

\section{Labour force shares, 1813-1871}

For the period 1813-1871, Shaw-Taylor's (2009a) estimates of the sectoral labour-force shares are used. These are derived from the population census data for the period 1851-71, and from Anglican parish registers for the period 1813-20. Table 6 presents data for males, females and the total occupied labour force. The results are very similar to the estimates of Mitchell (1988) for Great Britain although, strictly speaking, the data refer solely to England and Wales. For 1851-71 the share of the labour force in agriculture in England and Wales is very similar to Deane and Cole's (1967: 146) census-based estimate for Great Britain, while Mitchell (1988) offers comparable figures for the ratio of industrial to service sector workers. Nevertheless, Mitchell's data understate female agricultural employment (Higgs, 1987), hence Shaw-Taylor's data for England and Wales are preferred. The latter fit better with trends in female as well as male employment. Plainly, by the early nineteenth century Britain was highly industrialised, with around 45 per cent of the labour force in industry and less than a third of the labour force in agriculture. Services accounted for the remaining 24 per cent of the work force, the relatively substantial scale of this sector reflecting the by-then highly commercialised and closely governed state of the British economy.

\section{The issue of by-employment}

One obvious difficulty with allocating workers to specific occupations during the preindustrial centuries is the fact that many individuals combined more than one occupation. This issue of by-employment has been investigated for the early modern period by Saito (2010) and Shaw-Taylor (2009b), who conclude that a statistical assumption of complete 
occupational specialisation is unlikely to misrepresent too seriously the actual allocation of workers across the three main sectors. The reason for this is that where by-employment data do exist, they suggest that flows between sectors occurred in both directions, with only a relatively small net effect. Unfortunately, for the medieval period no systematic investigations of by-employment have been made. For want of evidence to the contrary, the same basic assumption, that any net effects of inter-sectoral flows in secondary occupations were small, has therefore been made for both the early modern and medieval periods. This is another area, like female labour force participation, where more quantitative research is needed.

\section{Long run trends in labour force shares}

Table 7B summarises the individual benchmark estimates set out in detail in Tables 1 to 6 . These figures build upon, and the exercise has been inspired by, the work of Shaw-Taylor $e t$ al. (2010), who have systematically re-worked the male and female occupational data for England and Wales from the population censuses for 1851-1871 and built up new estimates of male occupations from Anglican parish registers and other sources for 1710, 1755 and 1813-1820. The enduring differences between male and female participation in agriculture, industry and services are striking and emphasise the importance of factoring these contrasts into estimates of sectoral employment shares. Table 7B also highlights the scale of the structural shift away from agricultural employment which had already occurred before 1700 and the more modest scale of subsequent structural change between 1700 and 1871. After 1700 the proportion of the labour force engaged in agriculture certainly continued to erode as the shares of industry and services both rose but these changes were less dramatic than those suggested by earlier writers, including both Crafts (1985) and Deane and Cole (1967). The classic period of the Industrial Revolution therefore has to be seen more as a period of 
mechanisation and technological transformation than as an era of unusually rapid industrial occupational growth and structural change.

\section{OUTPUT SHARES AND PRODUCTIVITY}

The previous section has charted the post-1522 shift of labour away from agriculture. Over the same period sectoral output shares were also changing, with obvious implications for the productivities of labour employed in agriculture, industry and services. This section therefore presents data on the output shares of agriculture, industry and services in nominal value added. Relative sectoral incomes per worker can then be calculated by combining these output estimates with the estimates of sectoral employment. Real labour productivity by sector requires taking account of changes in relative prices, as discussed in Section IV.

Table 7A presents information on sectoral value-added shares from Broadberry et al. (2011). Indices of real output constructed by sector have been transformed into current price terms using sectoral price deflators, with absolute levels of GDP in current prices for each sector and for the total economy established using an input-output table for 1841 from Horrell et al. (1994). ${ }^{2}$ Table 7B restates the occupational shares from Tables 1-6, while Table 7C provides the sectoral incomes per worker relative to the average, derived from Parts A and B.

In 1700 agriculture's share of current value added was lower than that assumed by Crafts (1985: 16), who worked with a figure of 37 per cent, rather than the 26.7 per cent reported here. By the beginning of the nineteenth century, however, as noted by Crafts (1985: 61), agriculture no longer had an income per worker significantly below the economy-wide

\footnotetext{
${ }^{2}$ Horrell et al.'s (1994) data for the United Kingdom in 1841 have been adjusted to a Great Britain basis, with a further adjustment to an England-only basis at 1700 .
} 
average. The explanation seems to lie with the marked gain in the price of agricultural goods relative to the price of industrial goods which occurred during the long eighteenth century. This offset the effects of agriculture's below-average real output growth, so that agriculture's output share in current prices changed comparatively little. In contrast, incomes in industry and services were both higher than the economy-wide average before 1700. Thereafter, whereas industrial incomes were regressing to the mean, service-sector incomes were increasingly rising above the economy-wide average as commercial services grew in importance relative to domestic service.

\section{TRENDS IN LABOUR PRODUCTIVITY}

Table 8 sets out estimates of real labour productivity adjusted for the potentially distorting effect of changes in relative prices. Data on trends in real output are presented in Part A and the labour force in Part B. From these are derived the estimates of real labour productivity given in Part C. Finally, Part D presents annual growth rates for output, the labour force, and labour productivity for 1381-1700 and 1700-1851.

Several assumptions are necessary in order to derive labour-force estimates given in Table 8B from the population totals presented in Broadberry et al. (2011). First, the raw totals have been apportioned between males and females on the assumption of a $49: 51$ split in favour of females, based on census evidence for the nineteenth century. Second, those below the age of 16 are considered not to have been part of the labour force and that proportion is assumed to have been 37.5 per cent, in line with the assumptions made for the Poll Tax data and based on evidence from Wrigley and Schofield (1989). Third, labour-force participation rates of 97.1 per cent for males and 43.0 per cent for females estimated by Shaw-Taylor (2009a) for the nineteenth century are assumed to have been the norm in all earlier periods. 
The total labour force is then broken down by sector using the labour-force shares given in Tables 1 to 6 . The results are credible. Between the benchmark dates 1381 and 1522 the labour force declined slightly in agriculture and services, broadly in line with population, but grew in industry as the fledgling English cloth industry began to prosper. After 1522, with the resumption of population growth, the labour force grew in all three sectors, but much less rapidly in agriculture than in industry and services.

Labour productivity growth emerges as positive in all sectors both before and after 1700. Before 1700, the fastest growth was in services and the slowest growth in agriculture, but growth was little faster in industry, which was handicapped by mostly hand tools and a heavy reliance upon human energy. After 1700, the fastest growth was in industry and the slowest growth was in agriculture, as the former gained more from the development and adoption of labour-saving technology including wider application of the division of labour. It should be noted that this provides a more conventional picture of labour-productivity growth by sector before and during the Industrial Revolution than the suggestion implicit in the work of Crafts (1985) that productivity growth was faster in agriculture than in industry, as a result of a large structural shift of labour from agriculture to industry. Although that shift undoubtedly occurred, on the evidence of the estimates presented in this paper the bulk of it happened before rather than after 1700. Consequently, post-1700 labour-productivity growth in agriculture was slower than suggested by Crafts (1985), while industrial labourproductivity growth was correspondingly faster. Industrial development after 1700 was therefore much more a case of technologically driven mechanisation, than of output growth sustained primarily by expanding labour inputs. 
As well as returning to an earlier view of the Industrial Revolution, this paper also offers a drawn-out picture of the agricultural revolution spanning the long period surveyed by Overton (1996). The substantial shift of labour out of agriculture well before 1700 could not have been achieved without concomitant gains in agricultural labour productivity, as is consistent with the views of those who have stressed the agricultural achievements of the sixteenth and especially the seventeenth centuries (Kerridge, 1967; Jones, 1965; John 1976; Allen, 1992). From this early beginning, agricultural labour-productivity growth plainly gathered momentum during the eighteenth and nineteenth centuries, the period emphasised in the classic chronologies of the agricultural revolution (Toynbee, 1884; Ernle, 1912; Chambers and Mingay, 1966) and in Wrigley's more recent (2006) portrayal of the 'advanced organic economy'. The constraints of organic reproduction nevertheless ensured that, on the figures set out in Table 8, agriculture was the slowest growing sector both before and after 1700.

\section{1381 AND THE MALTHUSIAN DELUSION}

Clark (2011) presents independent estimates of the share of the labour force engaged in agriculture between 1381 and 1851. These are shown in Table 9 together with the estimates from this paper and those of Shaw-Taylor (2009a). It will be immediately apparent that there is no substantial disagreement over agriculture's share of the labour force at the beginning of the period in 1381 or at the end of the period in the 1860 s. Furthermore, in the sixteenth century the estimate of 58 per cent based on the Muster Rolls of 1522 is only slightly below the figure of 61 per cent derived by Clark et al. (2010) from a sample of wills for 1560-79. In the seventeenth century, however, Clark et al.'s (2010) figure of 59 per cent in 1652-60, again based on a sample of wills, looks high (even if taken to relate almost exclusively to males) relative to the estimates of 44 per cent for males and 38 per cent overall at the close of 
that century derived from Gregory King (Tables 3 and 9). The estimates presented in this paper imply that agriculture's share of the labour force was trending decisively downwards from at least the middle of the seventeenth century, declining to little more than 30 per cent by the beginning of the nineteenth century, whereas Clark et al. (2010) propose that the reduction commenced later and by the advent of the Industrial Revolution had proceeded less far. In particular, Clark's (2011) Figure 4 implies that further significant release of labour from agriculture was postponed until very late in the eighteenth century.

Clark's emphasis on the basic stability of agricultural employment during the lateseventeenth and eighteenth centuries runs counter to the weight of recent scholarship, which dates much of the release of labour from agriculture to the period before the mid-eighteenth century (Shaw-Taylor, 2009a; Shaw-Taylor et al., 2010). It is also difficult to reconcile with the dramatic increase in English urbanisation that occurred during the seventeenth century, from 5.8 per cent in 1600 to 13.3 per cent in 1700 (de Vries, 1984: 39). Citing Shaw-Taylor and Wrigley (2008) as their source, Clark et al. (2010) claim that in 1817 agriculture still employed 42 per cent of the labour force. There are at least two ways in which this is misleading. First, Shaw-Taylor and Wrigley explicitly indicate that their data refer exclusively to males. Second, they classify mining in the primary sector alongside agriculture rather than as part of industry. Correcting for employment differences between males and females and excluding miners from the agricultural labour force yields the revised ShawTaylor and Wrigley estimate of 31.4 per cent in 1813-20 shown in Table 9B.

Derived on a consistent basis, then, the agricultural labour-force share seems to have remained fairly constant at just under 60 per cent between 1381 and the early 1500 s, but by 1700 had shrunk to less than 40 per cent and by 1801 to just over 30 per cent. This is in line 
with the trend in GDP per capita outlined in Broadberry et al. (2011) and reproduced here in Figure 1. After rising sharply across the Black Death, GDP per capita remained on a plateau until the mid-seventeenth century and then trended steadily upwards. Yet while this bears out Clark's (2011) claim that agriculture's share of the labour force was inversely related to the level of GDP per capita, it is plainly at variance with his earlier (2007) and more controversial assertion that England in 1800 was no richer than in most of its history since 1200.

One way in which Clark (2011) tries to redeem his argument is by maximising the agricultural share of the labour force in 1817 , thereby creating the illusion that most of the occupational shift out of agriculture occurred after rather than before 1800. As well as reporting the higher figure for males only and including employment in mining, Clark (2011) further adjusts his figure upwards by making an allowance for imported food and agricultural raw materials, presumably on the grounds that without those imports, more people would have been required to work in the domestic agricultural sector. This is supposed to produce a 'corrected farm share'. Nevertheless, it should be noted that in deriving his relationship between GDP per capita and the share of the labour force in agriculture from data for the period 1946-2005, Clark takes no account of trade in agricultural goods, so there would be no justification for adjusting the historical data in this way.

One final point is worth emphasising in the light of the pictures of imposing Suffolk parish churches included in Clark's (2011) paper, all extensively rebuilt during the fifteenth century. ${ }^{3}$ Working back from the present with the modest growth rate of per capita income

\footnotetext{
${ }^{3}$ St Peter and St Paul Lavenham, one of the grandest of all English parish churches, was famously rebuilt to serve a thriving proto-industrial community between the 1480s and 1520 s with funds provided by the thirteenth earl of Oxford, three generations of the Spring family (all exceptionlly wealthy merchant clothiers), and other
} 
calculated by Broadberry et al. (2011) results in a GDP per capita in the 1450s of around $\$ 1,100$ in 1990 international prices. This is nearly treble Maddison's (2007) level of bare bones subsistence of around $\$ 400$, and is quite consistent with the built environment of the late medieval period and levels of non-agricultural employment, particularly in construction, which prevailed at that time. Indeed, it is perhaps surprising that Clark should choose to put so much emphasis on this architectural indicator of prosperity, given the dramatic urbanisation and transformation of the built environment that had occurred by the end of the eighteenth century (de Vries, 1984), by which time British GDP per capita had risen to $\$ 2,000$. This is just one of the many aspects of economic life which show a clear upward trend, including the growing diversity of diets (Feinstein, 1995; Woolgar et al., 2006), the availability of new and cheap consumer goods (Hersh and Voth, 2009), the growing wealth of testators (Overton et al., 2004; de Vries, 1994), the virtual elimination of famines (Campbell and Ó Gráda, 2011), the growth of publicly funded welfare provision (Slack, 1990), increasing literacy (Houstan, 1982; Schofield, 1973), and the growing diversity of occupations (Goose and Evans, 2000). The stagnation of daily real wage rates highlighted by Clark (2007; 2011) is also quite consistent with the rising GDP per capita estimated by Broadberry et al. (2011) if people increased the number of days worked per year (de Vries, 1994), if there was a distributional shift against labour, or if the relative price of basic consumption goods increased (Angeles, 2008). These issues are discussed in more detail in Broadberry et al. (2011).

\section{CONCLUDING COMMENTS}

The evidence presented in this paper suggests that the British economy was less overwhelmingly agricultural during the late-medieval and early modern periods than previous

local clothiers. The upper stage of the tower and south chantry chapel with its elaborate wooden screen were constructed with a bequest of $£ 200$ from Thomas Spring (d.1523). 
writers have assumed, with the implication that industry and services were both more developed. The proportion of the labour force in agriculture in both 1381 and 1522 is broadly consistent with the findings of Clark et al. (2010). Nevertheless, there remains a major disagreement over the trends in the labour-force share of agriculture between 1522 and 1851. Whereas Clark et al. (2010) detect no significant structural change before the late eighteenth century, the estimates presented here suggest that the critical occupational migration from agriculture to industry commenced some time after 1522 and had already made significant progress by 1700, leaving less scope for a dramatic shift of labour from agriculture to industry during the eighteenth and nineteenth centuries. This is in line with the recent findings of Shaw-Taylor (2009a). Since post-1700 growth rates of output by sector and in the aggregate economy remain broadly as suggested by Crafts and Harley (1992), this means that labour productivity growth was faster in industry and slower in agriculture.

The once orthodox view that industry was indeed the most dynamic sector during the classic Industrial Revolution is thus reinstated, along with the idea that mechanisation based upon technological advance delivered sustained productivity gains to Britain's slowly expanding industrial labour force. The fast commercialising service sector made steadier but cumulatively impressive gains so that, notwithstanding the much-vaunted achievements of the agricultural revolution, whether measured by output, employment, or labour productivity, agriculture was the slowest growing economic sector during 1700-1851. Although this work suggests that agricultural labour productivity was already rising during the early modern period, thus supporting an early start to the agricultural revolution, productivity growth also accelerated considerably during the eighteenth century, in line with the conventional chronology of the agricultural revolution. 
The substantial shift of labour out of agriculture between 1522 and 1800 is inconsistent with the "Malthusian delusion" of Clark (1381) that England experienced no trend growth in GDP per capita before the Industrial Revolution. The country after all was becoming more urbanised and the disproportionate growth of London was acting as an 'engine of growth' (Wrigley: 1967). Agriculture was an early beneficiary of the capital's insatiable appetite for provisions and organic raw materials, as is now acknowledged in accounts which stress the drawn-out character of England's agricultural revolution. The detailed work of Shaw-Taylor et al. (2010) establishes the quantitative dimensions of the structural transformation of the labour force which accompanied these early modern urban and agrarian developments. The reconstruction of British GDP from the output side by Broadberry et al. (2011) is also at variance with a Malthusian interpretation of the latemedieval and early modern British economy, insofar as population and GDP per capita (Figure 1) both trended upwards over time. Further research is needed on the issues of female labour-force participation and by-employment, but the broad trends of the long-run development of the British economy are now firmly established. In contrast to the postrenaissance stagnation and decline experienced by Italy (Malanima: 2011), Britain belonged to an elite club of north-west European countries whose economies displayed considerable dynamism and growth from the sixteenth century to the point in the nineteenth century when modern economic growth began. 
TABLE 1: Sectoral distribution of the male and female labour forces from the 1381 Poll Tax Returns

\section{A. Male workers}

\begin{tabular}{|c|c|c|c|c|c|c|}
\hline & \multicolumn{2}{|c|}{$\begin{array}{r}\text { Weighted } \\
\text { number of male } \\
\text { workers with } \\
\text { known } \\
\text { occupations } \\
\end{array}$} & \multicolumn{2}{|c|}{$\begin{array}{r}\text { Allocated male } \\
\text { labourers }\end{array}$} & \multicolumn{2}{|c|}{$\begin{array}{r}\text { Total male } \\
\text { workers }\end{array}$} \\
\hline & No. & $\%$ & No. & $\%$ & No. & $\%$ \\
\hline Agriculture & 14,351 & 67.0 & 2,526 & 67.0 & 16,877 & 67.0 \\
\hline Industry & 2,602 & 12.1 & 1,244 & 33.0 & 3,846 & 15.2 \\
\hline Services & 4,480 & 20.9 & 0 & 0.0 & 4,480 & 17.8 \\
\hline TOTAL & 21,433 & 100.0 & 3,770 & 100.0 & 25,203 & 100.0 \\
\hline
\end{tabular}

B. Female workers and total labour force

\begin{tabular}{|c|c|c|c|c|c|c|c|}
\hline & \multicolumn{2}{|c|}{$\begin{array}{r}\text { Weighted } \\
\text { number of } \\
\text { female workers } \\
\text { with known } \\
\text { occupations } \\
\end{array}$} & \multicolumn{2}{|c|}{$\begin{array}{r}\text { Allocated female } \\
\text { labourers }\end{array}$} & \multicolumn{2}{|c|}{$\begin{array}{r}\text { Total female } \\
\text { workers }\end{array}$} & \multirow[t]{2}{*}{$\begin{array}{r}\text { Total } \\
\text { labour } \\
\text { force } \\
\\
\%\end{array}$} \\
\hline & No. & $\%$ & No. & $\%$ & No. & $\%$ & \\
\hline Agriculture & 1,467 & 34.5 & 288 & 34.5 & 1,755 & 34.5 & 57.2 \\
\hline Industry & 899 & 21.1 & 547 & 65.5 & 1,446 & 28.4 & 19.2 \\
\hline Services & 1,888 & 44.4 & 0 & 0.0 & 1,888 & 37.1 & 23.6 \\
\hline TOTAL & 4,254 & 100.0 & 835 & 100.0 & 5,089 & 100.0 & 100.0 \\
\hline
\end{tabular}

Sources and notes: Male and female workers from Fenwick (1998; 2001; 2005). Workers with known occupations allocated to agriculture, industry and services using Wrigley's (2006) Primary-Secondary-Tertiary (PST) scheme, but with mining included in the industrial sector, as in Shaw-Taylor (2009a). Weights derived from the Cambridge Urban History of Britain as described in the text: urban $10 \%$, semi-rural $10 \%$, rural $80 \%$. Areas with more than $70 \%$ of occupations in agriculture are classified as rural, cities as identified in A. Dyer (2000) are classified as urban, and the rest are semi-rural. Labourers allocated between agriculture and non-agriculture in proportion to identified workers, but with all non-agricultural labourers allocated to industry. Females are assumed to account for 30 per cent of total employment, in line with Shaw-Taylor (2009a). 
TABLE 2: Sectoral distribution of the labour force from the 1522 Muster Rolls

A. Male workers with known occupations

\begin{tabular}{lrrrrr}
\hline & $\begin{array}{r}\text { Coventry } \\
\text { (urban) }\end{array}$ & $\begin{array}{r}\text { Babergh } \\
\text { (semi- } \\
\text { rural) }\end{array}$ & $\begin{array}{r}\text { Rutland } \\
\text { (rural) }\end{array}$ & \multicolumn{2}{c}{$\begin{array}{r}\text { Weighted number of } \\
\text { male workers with } \\
\text { known occupations }\end{array}$} \\
\cline { 5 - 7 } & No. & No. & No. & No & $\%$ \\
\hline Agriculture & 12 & 273 & 868 & 1,948 & 68.2 \\
Industry & 594 & 577 & 38 & 461 & 16.2 \\
Services & 143 & 133 & 218 & 446 & 15.6 \\
ToTAL & 749 & 983 & 1,124 & 2,856 & 100.0 \\
\hline
\end{tabular}

B. Male and female workers, with labourers allocated

\begin{tabular}{|c|c|c|c|c|c|c|}
\hline & \multicolumn{2}{|c|}{$\begin{array}{r}\text { Allocated male } \\
\text { labourers }\end{array}$} & \multicolumn{2}{|c|}{$\begin{array}{r}\text { Total male } \\
\text { workers }\end{array}$} & \multirow{2}{*}{$\begin{array}{l}\begin{array}{l}\text { Total } \\
\text { female } \\
\text { workers }\end{array} \\
\%\end{array}$} & \multirow{2}{*}{$\begin{array}{r}\text { Total } \\
\text { labour } \\
\text { force } \\
\%\end{array}$} \\
\hline & No. & $\%$ & No. & $\%$ & & \\
\hline Agriculture & 679 & 68.2 & 2,627 & 68.2 & 34.5 & 58.1 \\
\hline Industry & 317 & 31.8 & 778 & 20.2 & 28.4 & 22.7 \\
\hline Services & 0 & 0.0 & 446 & 11.6 & 37.1 & 19.2 \\
\hline TOTAL & 996 & 100.0 & 3,852 & 100.0 & 100.0 & 100.0 \\
\hline
\end{tabular}

Sources and notes: Part A: Coventry: Hulton (1999); Babergh: Pound (1986); Rutland: Cornwall (1980); Workers with known occupations allocated to agriculture, industry and services using Wrigley's (2006) PST scheme, but with mining included in the industrial sector, as in Shaw-Taylor (2009a). Weights derived from Cambridge Urban History of Britain as described in the text: Coventry (urban) 10\%, Babergh (semi-rural) 10\%, Rutland (rural) 80\%. Part B: Labourers allocated between agriculture and non-agriculture in proportion to identified workers, but with all non-agricultural labourers allocated to industry. Female distribution of labour force assumed to be the same as in 1381, and females assumed to account for 30 per cent of total employment, in line with Shaw-Taylor (2009a). 
TABLE 3: Sectoral distribution of the labour force from a social table, circa 1700

\section{A. Male workers}

\begin{tabular}{|c|c|c|c|}
\hline & $\begin{array}{r}\text { 'Family' } \\
\text { numbers } \\
\text { according to } \\
\text { King }^{1}\end{array}$ & $\begin{array}{r}\text { 'Family' } \\
\text { numbers } \\
\text { adjusted for } \\
\text { labourers \& } \\
\text { servants } \\
1\end{array}$ & $\begin{array}{r}\text { Labour-force } \\
\text { shares }(2,3, \& \\
4 \text { as } \% \text { of } 7)\end{array}$ \\
\hline $\begin{array}{l}\text { High titles \& gentlemen } \\
\text { Vagrants } \\
\text { 1. UNOCCUPIED }\end{array}$ & $\begin{array}{l}19,626 \\
23,489\end{array}$ & $\begin{array}{l}19,626 \\
23,489 \\
43,115\end{array}$ & \\
\hline $\begin{array}{l}\text { Agriculture } \\
\text { Agricultural labourers } \\
\text { 2. AgRICULTURE }\end{array}$ & $\begin{array}{r}227,440 \\
\text { Included in } 5 .\end{array}$ & $\begin{array}{l}227,440 \\
407,959 \\
635,399\end{array}$ & 46.0 \\
\hline $\begin{array}{l}\text { Industry and building } \\
\text { Industrial labourers }{ }^{3} \\
\text { 3. INDUSTRY }\end{array}$ & $\begin{array}{r}256,866 \\
\text { Included in } 5 .\end{array}$ & $\begin{array}{l}256,866 \\
190,221 \\
447,087\end{array}$ & 32.3 \\
\hline $\begin{array}{l}\text { Commerce } \\
\text { Professions } \\
\text { Military \& maritime } \\
\text { Domestic servants }{ }^{4} \\
\text { 4. SERVICES }\end{array}$ & $\begin{array}{r}128,025 \\
42,960 \\
94,000 \\
\text { Omitted }\end{array}$ & $\begin{array}{r}128,025 \\
42,960 \\
94,000 \\
34,765 \\
299,750\end{array}$ & 21.7 \\
\hline $\begin{array}{l}\text { 5. LABOURERS, COTTAGERS \& } \\
\text { PAUPERS }\end{array}$ & 598,180 & & \\
\hline 6. TOTAL (1-5) & $1,390,586$ & & \\
\hline 7. TOTAL OCCUPIED (2-4) & & $1,382,236$ & 100.0 \\
\hline
\end{tabular}

B. Total labour force $(\%)$

\begin{tabular}{lrrr}
\hline & Males & Females $^{5}$ & Total $^{6}$ \\
\hline Agriculture & 46.0 & 22.3 & 38.9 \\
Industry & 32.3 & 37.8 & 34.0 \\
Services & 21.7 & 39.9 & 27.2 \\
TOTAL & 100.0 & 100.0 & 100.0 \\
\hline
\end{tabular}

Sources and notes: Derived from King [1696]; Lindert and Williamson (1982: 388); and Crafts (1985: 13-15).

${ }^{1}$ Assumed to apply to males only.

${ }^{2}$ Estimated at $68.2 \%$ of the 598,180 'Labourers, cottagers and paupers'.

${ }^{3}$ Estimated at $31.8 \%$ of the 598,180 'Labourers, cottagers and paupers'.

${ }^{4}$ Male domestic servants estimated at $2.5 \%$ of King's total families (6.)

${ }^{5}$ Female labour distributed across sectors in line with the 1813-20 shares from Shaw-Taylor (2009a).

${ }^{6}$ Females assumed to account for $30 \%$ of total employment, in line with Shaw-Taylor (2009a). 
TABLE 4: Sectoral distribution of the labour force from a social table, circa 1759

\section{A. Male workers}

\begin{tabular}{|c|c|c|c|}
\hline & $\begin{array}{r}\text { 'Family' } \\
\text { numbers } \\
\text { according to } \\
\text { Massie }^{1}\end{array}$ & $\begin{array}{r}\text { 'Family' } \\
\text { numbers } \\
\text { adjusted for } \\
\text { labourers \& } \\
\text { servants }\end{array}$ & $\begin{array}{r}\text { Labour-force } \\
\text { shares }(2,3, \& \\
4 \text { as } \% \text { of } 7)\end{array}$ \\
\hline $\begin{array}{l}\text { High titles \& gentlemen } \\
\text { Vagrants } \\
\text { 1. UNOCCUPIED }\end{array}$ & $\begin{array}{l}18,070 \\
13,418\end{array}$ & $\begin{array}{l}18,070 \\
13,418 \\
31,488\end{array}$ & \\
\hline $\begin{array}{l}\text { Agriculture } \\
\text { Agricultural labourers }{ }^{2} \\
\text { 2. AgRICULTURE }\end{array}$ & $\begin{array}{r}379,008 \\
\text { Included in } 5 .\end{array}$ & $\begin{array}{l}379,008 \\
285,684 \\
664,692\end{array}$ & 43.0 \\
\hline $\begin{array}{l}\text { Industry and building } \\
\text { Industrial labourers } \\
\text { 3. INDUSTRY }\end{array}$ & $\begin{array}{r}366,252 \\
\text { Included in } 5 .\end{array}$ & $\begin{array}{l}366,252 \\
133,208 \\
499,460\end{array}$ & 32.3 \\
\hline $\begin{array}{l}\text { Commerce } \\
\text { Professions } \\
\text { Military \& maritime } \\
\text { Domestic servants }{ }^{4} \\
\text { 4. SERVICES }\end{array}$ & $\begin{array}{r}200,500 \\
57,000 \\
86,000 \\
\text { Omitted }\end{array}$ & $\begin{array}{r}200,500 \\
57,000 \\
86,000 \\
38,479 \\
381,979\end{array}$ & 24.7 \\
\hline $\begin{array}{l}\text { 5. LABOURERS, COTTAGERS \& } \\
\text { PAUPERS }\end{array}$ & 418,892 & & \\
\hline 6. TOTAL (1-5) & $1,539,140$ & & \\
\hline 7. TOTAL OCCUPIED (2-4) & & $1,546,131$ & 100.0 \\
\hline
\end{tabular}

B. Total labour force $(\%)$

\begin{tabular}{lrrr}
\hline & Males & Females $^{5}$ & Total $^{6}$ \\
\hline Agriculture & 43.0 & 22.3 & 36.8 \\
Industry & 32.3 & 37.8 & 33.9 \\
Services & 24.7 & 39.9 & 29.3 \\
TOTAL & 100.0 & 100.0 & 100.0 \\
\hline
\end{tabular}

Sources and notes: Derived from Massie [1760]; Lindert and Williamson (1982: 388); and Crafts (1985: 13-15).

${ }^{1}$ Assumed to apply to males only.

${ }^{2}$ Estimated at $68.2 \%$ of the 418,892 'Labourers, cottagers and paupers'.

${ }^{3}$ Estimated at $31.8 \%$ of the 418,892 'Labourers, cottagers and paupers'.

${ }^{4}$ Male domestic servants estimated at $2.5 \%$ of Massie's total families (6.)

${ }^{5}$ Female labour distributed across sectors in line with the 1813-20 shares from Shaw-Taylor (2009a).

${ }^{6}$ Females assumed to account for $30 \%$ of total employment, in line with Shaw-Taylor (2009a). 
TABLE 5: Sectoral distribution of the labour force from a social table, circa 1801

A. Male workers

\begin{tabular}{|c|c|c|c|}
\hline & $\begin{array}{r}\text { 'Family' } \\
\text { numbers } \\
\text { according to } \\
\text { Colquhoun }{ }^{1}\end{array}$ & $\begin{array}{r}\text { 'Family' } \\
\text { numbers } \\
\text { adjusted for } \\
\text { labourers \& } \\
\text { servants }\end{array}$ & $\begin{array}{r}\text { Labour-force } \\
\text { shares }(2,3, \& \\
4 \text { as } \% \text { of } 7)\end{array}$ \\
\hline $\begin{array}{l}\text { High titles \& gentlemen } \\
\text { Vagrants } \\
\text { 1. UNOCCUPIED }\end{array}$ & $\begin{array}{r}27,203 \\
179,718\end{array}$ & $\begin{array}{r}27,203 \\
179,718 \\
206,921\end{array}$ & \\
\hline $\begin{array}{l}\text { Agriculture } \\
\text { Agricultural labourers }{ }^{2} \\
\text { 2. AgRICULTURE }\end{array}$ & $\begin{array}{r}320,000 \\
\text { Included in } 5 .\end{array}$ & $\begin{array}{l}320,000 \\
409,322 \\
729,322\end{array}$ & 35.7 \\
\hline $\begin{array}{l}\text { Industry and building } \\
\text { Industrial labourers }{ }^{3} \\
\text { 3. INDUSTRY }\end{array}$ & $\begin{array}{r}541,026 \\
\text { Included in } 5 .\end{array}$ & $\begin{array}{l}541,026 \\
190,857 \\
731,883\end{array}$ & 35.9 \\
\hline $\begin{array}{l}\text { Commerce } \\
\text { Professions } \\
\text { Military \& maritime } \\
\text { Domestic servants }{ }^{4} \\
\text { 4. SERVICES }\end{array}$ & $\begin{array}{r}205,800 \\
74,840 \\
244,348 \\
\text { Omitted }\end{array}$ & $\begin{array}{r}205,800 \\
74,840 \\
244,348 \\
54,828 \\
579,816\end{array}$ & 28.4 \\
\hline $\begin{array}{l}\text { 5. LABOURERS, COTTAGERS \& } \\
\text { PAUPERS }\end{array}$ & 600,179 & & \\
\hline 6. TOTAL (1-5) & $2,193,114$ & & \\
\hline 7. TOTAL OCCUPIED (2-4) & & $2,041,021$ & 100.0 \\
\hline
\end{tabular}

B. Total labour force $(\%)$

\begin{tabular}{lrrr}
\hline & Males & Females $^{5}$ & Total $^{6}$ \\
\hline Agriculture & 35.7 & 22.3 & 31.7 \\
Industry & 35.9 & 37.8 & 36.4 \\
Services & 28.4 & 39.9 & 31.9 \\
TOTAL & 100.0 & 100.0 & 100.0 \\
\hline
\end{tabular}

Sources and notes: Derived from Colquhoun (1806); Lindert and Williamson (1982: 388); and Crafts (1985: 13-15).

${ }^{1}$ Assumed to apply to males only.

${ }^{2}$ Estimated at $68.2 \%$ of the 600,179 'Labourers, cottagers and paupers'.

${ }^{3}$ Estimated at $31.8 \%$ of the 600,179 'Labourers, cottagers and paupers'.

${ }^{4}$ Male domestic servants estimated at $2.5 \%$ of Colquhoun's total families (6.)

${ }^{5}$ Female labour distributed across sectors in line with the 1813-20 shares from Shaw-Taylor (2009a).

${ }^{6}$ Females assumed to account for $30 \%$ of total employment, in line with Shaw-Taylor (2009a). 
TABLE 6: Sectoral distribution of the labour force, England and Wales 1813-1871 (\%)

\section{A. Males}

\begin{tabular}{lrrrr}
\hline & $1813-20$ & 1851 & 1861 & \multicolumn{1}{c}{1871} \\
\hline Agriculture & 35.4 & 27.2 & 24.4 & 19.8 \\
Industry & 47.4 & 50.1 & 49.6 & 52.6 \\
Services & 17.2 & 22.7 & 26.0 & 27.6 \\
TOTAL & 100.0 & 100.0 & 100.0 & 100.0 \\
\hline B. Females & & & & \\
\hline Agriculture & 22.3 & 15.6 & 12.6 & 11.2 \\
Industry & 37.8 & 36.4 & 38.3 & 35.8 \\
Services & 39.9 & 48.0 & 49.1 & 53.0 \\
TOTAL & 100.0 & 100.0 & 100.0 & 100.0 \\
\hline C. Males and females & & & & \\
\hline Agriculture & 31.4 & 23.5 & 20.6 & 16.9 \\
Industry & 44.5 & 45.7 & 45.9 & 47.1 \\
Services & 24.1 & 30.9 & 33.5 & 36.0 \\
ToTAL & 100.0 & 100.0 & 100.0 & 100.0 \\
\hline
\end{tabular}

Sources: Shaw-Taylor (2009a). 
TABLE 7: Sectoral shares in British GDP, 1700-1851 (\%)

\section{A. Sectoral value added shares}

\begin{tabular}{lrrrrrr}
\hline & 1381 & 1522 & 1700 & 1759 & 1801 & 1851 \\
\hline Agriculture & 45.5 & 39.7 & 26.7 & 29.7 & 31.4 & 18.7 \\
Industry & 28.8 & 38.7 & 41.3 & 35.2 & 32.7 & 32.1 \\
Services & 25.7 & 21.6 & 32.0 & 35.1 & 36.0 & 49.2 \\
GDP & 100.0 & 100.0 & 100.0 & 100.0 & 100.0 & 100.0 \\
\hline
\end{tabular}

B. Occupational shares

\begin{tabular}{lrrrrrr}
\hline Agriculture & 57.3 & 58.1 & 38.9 & 36.8 & 31.7 & 23.5 \\
Industry & 19.2 & 22.7 & 34.0 & 33.9 & 36.4 & 45.6 \\
Services & 23.6 & 19.2 & 27.2 & 29.3 & 31.9 & 30.9 \\
GDP & 100.0 & 100.0 & 100.0 & 100.0 & 100.0 & 100.0 \\
\hline \multirow{2}{*}{ C. Sectoral income per worker } & & & & & \\
\hline Agriculture & 79.5 & 68.4 & 68.7 & 80.8 & 98.9 & 79.6 \\
Industry & 150.1 & 170.6 & 121.5 & 103.8 & 89.7 & 70.3 \\
Services & 109.1 & 112.5 & 117.9 & 119.9 & 112.9 & 159.3 \\
GDP & 100.0 & 100.0 & 100.0 & 100.0 & 100.0 & 100.0 \\
\hline
\end{tabular}

Sources and notes: Part A: Derived from Broadberry et al. (2011). Part B: Tables 1-6. Part C: Derived by dividing Part A by Part B. Before 1700, the estimates are derived from data referring only to the territory of England. 
TABLE 8: Trends in British output, labour force and labour productivity (1700=100)

A. Output

\begin{tabular}{lrrrrrr}
\hline & 1381 & 1522 & 1700 & 1759 & 1801 & 1851 \\
\hline Agriculture & 50.9 & 51.3 & 100.0 & 159.2 & 227.0 & 328.3 \\
Industry & 18.9 & 27.6 & 100.0 & 144.7 & 275.2 & $1,206.3$ \\
Services & 24.8 & 27.1 & 100.0 & 150.9 & 266.6 & 777.4 \\
GDP & 29.2 & 34.2 & 100.0 & 150.4 & 251.6 & 711.5 \\
\hline
\end{tabular}

B. Labour force

\begin{tabular}{lrrrrrr}
\hline & 1381 & 1522 & 1700 & 1759 & 1801 & 1851 \\
\hline Agriculture & 68.7 & 67.6 & 100.0 & 114.2 & 137.1 & 144.0 \\
Industry & 26.3 & 30.2 & 100.0 & 120.3 & 180.3 & 327.4 \\
Services & 40.5 & 32.1 & 100.0 & 130.0 & 197.2 & 309.4 \\
GDP & 46.6 & 45.2 & 100.0 & 120.6 & 168.1 & 251.2 \\
\hline
\end{tabular}

C. Labour productivity

\begin{tabular}{lrrrrrr}
\hline & 1381 & 1522 & 1700 & 1759 & 1801 & 1851 \\
\hline Agriculture & 74.2 & 75.9 & 100.0 & 139.5 & 165.6 & 228.0 \\
Industry & 71.8 & 91.6 & 100.0 & 120.3 & 152.7 & 368.5 \\
Services & 61.3 & 84.6 & 100.0 & 116.1 & 135.2 & 251.3 \\
GDP & 62.6 & 75.7 & 100.0 & 124.7 & 149.7 & 283.2 \\
\hline
\end{tabular}

D. Annual growth rates $(\%)$

\begin{tabular}{lrrrrrr}
\hline & \multicolumn{2}{c}{ A. Output: } & \multicolumn{2}{c}{ B. Labour force: } & \multicolumn{2}{c}{ C. Labour productivity: } \\
& $1381-1700$ & $1700-1851$ & $1381-1700$ & $1700-1851$ & $1381-1700$ & $1700-1851$ \\
\hline Agriculture & 0.21 & 0.79 & 0.12 & 0.24 & 0.09 & 0.55 \\
Industry & 0.52 & 1.66 & 0.42 & 0.79 & 0.10 & 0.87 \\
Services & 0.44 & 1.37 & 0.28 & 0.75 & 0.16 & 0.62 \\
GDP & 0.39 & 1.31 & 0.24 & 0.61 & 0.15 & 0.70 \\
\hline
\end{tabular}

Sources and notes: Part A: Output derived from Broadberry et al. (2011). Data reported for 10-year averages. Part B: Population from Broadberry et al. (2011), allocated as 51 per cent female and 49 per cent male before 1801. Male and female proportions after 1801 from Wrigley (2011). Population of working age derived on the assumption of 37.5 per cent below age 16. Labour force derived on the assumption of a participation rate of 97.1 per cent for males and 43.0 per cent for females. Labour force by sector derived using the shares for appropriate years from Tables 1 to 6. Part C: Derived by dividing part A by part B. Part D; Derived from Parts A-C. Before 1700, the estimates are derived from data referring only to the territory of England. 
TABLE 9: Share of the English labour force engaged in agriculture, 1381-1869 (\%)

\begin{tabular}{|c|c|c|c|c|c|c|c|c|c|}
\hline & \multicolumn{3}{|c|}{ A. This paper } & \multicolumn{3}{|c|}{ B. Shaw-Taylor } & \multicolumn{3}{|c|}{ C. Clark } \\
\hline & Males & Females & Total & Males & Females & Total & Males & Females & Total \\
\hline 1381 & 67.0 & 34.5 & 57.2 & & & & 61 & 43 & $56-59$ \\
\hline 1522 & 68.2 & 34.5 & 58.1 & & & & & & \\
\hline $1560-79$ & & & & & & & & & 61 \\
\hline $1652-60$ & & & & & & & & & 59 \\
\hline 1700 & 46.0 & 22.3 & 38.9 & & & & & & \\
\hline 1710 & & & & 43.0 & & & & & \\
\hline 1755 & & & & 44.0 & & & & & \\
\hline 1759 & 43.0 & 22.3 & 36.8 & & & & & & \\
\hline 1801 & 35.7 & 22.3 & 31.7 & & & & & & \\
\hline $1813-20$ & & & & 35.4 & 22.3 & 31.4 & 42 & & \\
\hline 1851 & 27.2 & 15.6 & 23.5 & 27.2 & 15.6 & 23.5 & & & \\
\hline 1861 & 24.4 & 12.6 & 20.6 & 24.4 & 12.6 & 20.6 & & & ${ }^{\mathrm{a}} 20$ \\
\hline
\end{tabular}

Sources and notes: Part A: Tables 1-5; Part B: Shaw-Taylor (2009a); Shaw-Taylor et al. (2010); Part C: Clark (2011: Table 2); Clark et al. (2010: Table 6).

a 1860-69 
FIGURE 1: British GDP per capita $(1700=100)$



Source: Broadberry et al. (2011). 


\section{REFERENCES}

Allen, R.C. (1992), Enclosure and the Yeoman, Oxford: Clarendon.

Allen, R.C. (2000), "Economic Structure and Agricultural Productivity in Europe, 13001800”, European Review of Economic History, 3, 1-25.

Angeles, L. (2008), “GDP per capita or Real Wages? Making Sense of Conflicting Views on Pre-industrial Europe", Explorations in Economic History, 45, 147-163.

Barron, C.M. (2000), "London 1300-1540", in Palliser, D.M. (ed.), The Cambridge Urban History of Britain, Volume 1, 600-1540, Cambridge: Cambridge University Press, 395-440.

Broadberry, S.N., Campbell, B., Klein, A., Overton, M. and van Leeuwen, B. (2011), "British Economic Growth, 1270-1870: An Output-Based Approach", London School of Economics, http://www2.1se.ac.uk/economicHistory/whosWho/profiles/sbroadberry.aspx.

Campbell, B.M. S., and Ó Gráda, C. (2011), "Harvest Shortfalls, Grain Prices, and Famines in Pre-Industrial England”, Journal of Economic History, 71 (forthcoming).

Chambers, J.D. and Mingay, G.E. (1966), The Agricultural Revolution, 1750-1850, London: Batsford.

Clark, G. (2007), A Farewell to Alms: A Brief Economic History of the World, Princeton: Princeton University Press.

Clark, G. (2011), “1381 and the Malthus Delusion”, Explorations in Economic History, (forthcoming).

Clark, G., Cummins, J. and Smith, B. (2010), "The Surprising Wealth of Pre-industrial England", University of California, Davis, http://www.econ.ucdavis.edu/faculty/gclark/research.html.

Colquhoun, P. (1806), A Treatise on Indigence, London: J. Hatchard.

Cornwall, J. (ed.) (1980), The County Community under Henry VIII: The Military Survey, 1522 and the Lay Subsidy, 1524-5, Oakham: Rutland Record Society.

Crafts, N.F.R. (1985), British Economic Growth during the Industrial Revolution, Oxford: Oxford University Press.

Crafts, N.F.R. (1989), "British Industrialization in and International Context", Journal of Interdisciplinary History, 19, 415-428.

Crafts, N.F.R. and Harley, C.K. (1992), Output Growth and the British Industrial Revolution: A Restatement of the Crafts-Harley View", Economic History Review, 45, 703-770. 
Deane, P. and Cole, W.A. (1967), British Economic Growth, 1688-1959: Trends and Structure, $2^{\text {nd }}$ edition, Cambridge: Cambridge University Press.

Dyer, A. (2000), “Appendix: Ranking Lists of English Medieval Towns”, in Palliser, D.M. (ed.), The Cambridge Urban History of Britain, Volume 1, 600-1540, Cambridge: Cambridge University Press, 747-770.

Dyer, C. (2000), "Small Towns 1270-1540", in Palliser, D.M. (ed.), The Cambridge Urban History of Britain, Volume 1, 600-1540, Cambridge: Cambridge University Press, 505-537.

Ernle, Lord [formerly Prothero, R.E.] (1912), English Farming, Past and Present, London: Heinemann.

Feinstein, C.H. (1995), "Changes in Nominal Wages, the Cost of Living and Real Wages in the United Kingdom over two Centuries, 1780-1990", in Scholliers, P. and Zamagni, V. (eds.), Labour's Reward: Real Wages and Economic Change in $19^{\text {th }}$ - and $20^{\text {th }}$ Century Europe, Aldershot: Elgar, 3-36.

Fenwick, C.C. (ed.) (1998), The Poll Taxes of 1377, 1379 and 1381, Part 1: Bedfordshire Leicestershire, Oxford: British Academy and Oxford University Press.

Fenwick, C.C. (ed.) (2001), The Poll Taxes of 1377, 1379 and 1381, Part 2: Lincolnshire Westmorland, Oxford: British Academy and Oxford University Press.

Fenwick, C.C. (ed.) (2005), The Poll Taxes of 1377, 1379 and 1381, Part 3: Wiltshire Yorkshire, Oxford: British Academy and Oxford University Press.

Field, J. and Erickson, A. (2009), "Prospects and Preliminary Work on Female Occupational Structure in England from 1500 to the National Census", Cambridge Group for the History of Population and Social Structure, Occupations Project Paper No.18, http://www.geog.cam.ac.uk/research/projects/occupations/abstracts/.

Goose, N. and evans, N. (2000), "'Wills as an Historical Source", in Arkell, T., Evans, N. and Goose, N. (eds.), When Death Do Us Part: Understanding and Interpreting the Probate Records of Early Modern England, Oxford: Leopard's Head.

Hersh, J. and Voth, H.-J. (2009), "Sweet Diversity: Colonial Goods and the Rise of European Living Standards after 1492", unpublished working paper, University of Pennsylvania and Universitat Pompeu Fabra, http://papers.ssrn.com/sol3/papers.cfm?abstract_id=1402322.

Higgs, E. (1987), "Women, Occupations and Work in the Nineteenth Century Censuses", History Workshop Journal, 23, 59-80.

Horrell, S., Humphries, J. and Weale, M. (1994), “An Input-Output Table for 1841", Economic History Review, 47, 545-566.

Houstan, R.A. (1982), "The Development of Literacy: Northern England, 1640-1750", Economic History Review, 35, 199-216. 
Hulton, M.H.M. (ed.) (1999), Coventry and its People in the 1520s, Stratford-upon-Avon: The Dugdale Society.

Humphries, J. (2010), Childhood and Child Labour in the British Industrial Revolution, Cambridge: Cambridge University Press.

John, A.H. (1976), "English Agricultural Improvements and Grain Exports, 1660-1765", in Coleman, D.C. and John, A.H. (eds.), Trade, Government and Economy in PreIndustrial England, London: Weidenfeld and Nicolson, 45-67.

Jones, E.L. (1965), “Agriculture and Economic Growth in England, 1660-1750: Agricultural Change", Journal of Economic History, 25, 1-18.

Kermode, J. (2000), "The Greater Towns", in Palliser, D.M. (ed.), The Cambridge Urban History of Britain, Volume 1, 600-1540, Cambridge: Cambridge University Press, 441-465.

Kerridge, E. (1967), The Agricultural Revolution, London: George Allen \& Unwin.

King, G. [1696] (1936), "Natural and Political Observations and Conclusions upon the State and Condition of England", in Barnett, G.E. (ed.), Two Tracts by Gregory King, Baltimore: Johns Hopkins Press.

Lindert, P.H. and Williamson, J.G. (1982), "Revising England's Social Tables, 1688-1812”, Explorations in Economic History, 19, 385-408.

Maddison, A. (2007), Contours of the World Economy, 1-2030 AD: Essays in MacroEconomic History, Oxford: Oxford University Press.

Malanima, Paolo (2011), "The Long Decline of a Leading Economy: GDP in Central and Northern Italy, 1300-1913”, European Review of Economic History, 15, 169-219

Massie, J. [1760] (2010), "[Appendix] A Computation of the Money that Hath been Exorbitantly Raised upon the People of great Britain by the Sugar-Planters, in One Year, from January 1759 to January 1760; Shewing How Much Money a Family of Each Rank, Degree or Class Hath Lost by that Rapacious Monoply Having Continued so Long after I Laid it Open, in my State of the British Sugar-Colony Trade, which was Published Last Winter", London.The Making of the Modern World, Gale, Cengage Learning.

Mitchell, B.R. (1988), British Historical Statistics, Cambridge: Cambridge University Press.

Overton, M. (1996), Agricultural Revolution in England: The Transformation of the Agrarian Economy, 1500-1850, Cambridge: Cambridge University Press.

Overton, M. and Campbell, B.M.S. (1996), "Production et productivité dans l'agriculture anglais, 1086-1871", Histoire et Mesure, 11, 255-297. 
Overton, M., Whittle, J., Dean, D. and Haan, A. (2004), Production and Consumption in English Households, 1600-1750, London: Routledge.

Pound, J. (ed.) (1986), The Military Survey of 1522 for Babergh Hundred, Woodbridge: Suffolk Records Society and Boydell Press.

Saito, O. (2010), "By-employment and Historical Occupational Structures in Comparative Perspective", paper presented at Economic History Society Conference, University of Durham.

Schofield, R.S. (1973), "Dimensions of Illiteracy, 1750-1850", Explorations in Economic History, 10, 437-454.

Shaw-Taylor, L. (2009a), “The Occupational Structure of England and Wales, c.1750-1911”, Cambridge Group for the History of Population and Social Structure, Occupations Project Paper No.19, http://www.geog.cam.ac.uk/research/projects/occupations/abstracts/.

Shaw-Taylor, L. (2009b), "The Nature and Scale of the Cottage Economy", Cambridge Group for the History of Population and Social Structure, Occupations Project Paper No.15, http://www.hpss.geog.cam.ac.uk/research/projects/occupations/abstracts/.

Shaw-Taylor, L. and Wrigley, E.A. (2008), "The Occupational Structure of England c. 17501871: A Preliminary Report", Cambridge Group for the History of Population and Social Structure, Occupations Project Paper No.1, http://www.geog.cam.ac.uk/research/projects/occupations/abstracts/.

Shaw-Taylor, L., Wrigley, E.A., Kitson, P., Davies, R., Newton, G. and Satchell, M. (2010), "The Occupational Structure of England, c.1710-1871", Cambridge Group for the History of Population and Social Structure, Occupations Project Paper No.22, http://www.geog.cam.ac.uk/research/projects/occupations/abstracts/.

Slack, P. (1990), The English Poor Law, 1531-1782, London: Macmillan.

Toynbee, A. (1994), Lectures on the Industrial Revolution of the 18th Century in England, London: Longmans Green.

de Vries, J. (1984), European Urbanization 1500-1800, London: Methuen.

de Vries, J. (1994), “The Industrial Revolution and the Industrious Revolution", Journal of Economic History, 54, 249-270.

Woolgar, C.M., Serjeantson, D. and Waldron, T. (2006), "Introduction", in Woolgar, C.M., Serjeantson, D. and Waldron, T. (eds.), Food in Medieval England: Diet and Nutrition, Oxford: Oxford University Press, 1-8.

Wrigley, E. A. (1967), “A Simple Model of London's Importance in Changing English Society and Economy 1650-1750", Past and Present, 37, 44-70 
Wrigley, E.A. and Schofield, R.S. (1989), The Population History of England, 1541-1871: A Reconstruction, Cambridge: Cambridge University Press.

Wrigley, E.A. (2006), “Categorising Occupations: The Primary, Secondary, Tertiary (PST) System”, Department of Geography, University of Cambridge,

http://www.geog.cam.ac.uk/research/projects/occupations/categorisation/.

Wrigley, E. A. (2006), "The Transition to an Advanced Organic Economy: Half a Millennium of English Agriculture”, Economic History Review, 59, 435-80.

Wrigley, E.A. (2011), The Early English Censuses, British Academy Records of Social and Economic History, Oxford: Oxford University Press, (forthcoming). 